\title{
Preliminary Definition of Geophysical Regions in Western Eurasia
}

J. Bhattacharyya, W.R. Walter, M.P. Flanagan, J. O'Boyle and M.E. Pasyanos

\section{April 3, 2000}

U.S. Department of Energy

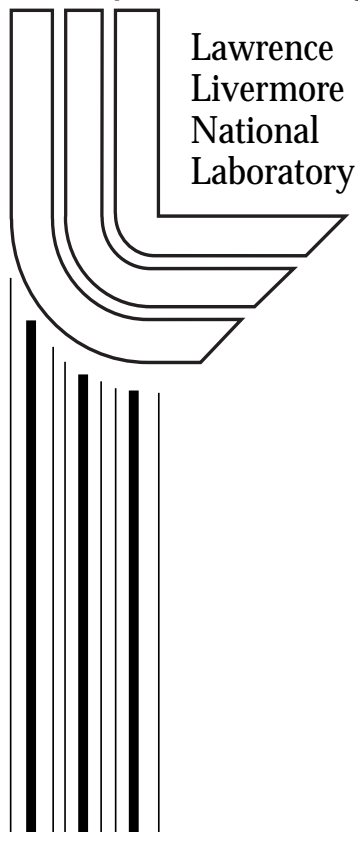




\section{DISCLAIMER}

This document was prepared as an account of work sponsored by an agency of the United States Government. Neither the United States Government nor the University of California nor any of their employees, makes any warranty, express or implied, or assumes any legal liability or responsibility for the accuracy, completeness, or usefulness of any information, apparatus, product, or process disclosed, or represents that its use would not infringe privately owned rights. Reference herein to any specific commercial product, process, or service by trade name, trademark, manufacturer, or otherwise, does not necessarily constitute or imply its endorsement, recommendation, or favoring by the United States Government or the University of California. The views and opinions of authors expressed herein do not necessarily state or reflect those of the United States Government or the University of California, and shall not be used for advertising or product endorsement purposes.

Work performed under the auspices of the U. S. Department of Energy by the University of California Lawrence Livermore National Laboratory under Contract W-7405-Eng-48.

This report has been reproduced directly from the best available copy.

Available to DOE and DOE contractors from the

Office of Scientific and Technical Information

P.O. Box 62, Oak Ridge, TN 37831

Prices available from (423) 576-8401

http://apollo.osti.gov/bridge/

Available to the public from the National Technical Information Service

U.S. Department of Commerce 5285 Port Royal Rd., Springfield, VA 22161 http://www.ntis.gov/

OR

Lawrence Livermore National Laboratory Technical Information Department's Digital Library http://www.llnl.gov/tid/Library.html 


\title{
Preliminary Definition of Geophysical Regions in Western Eurasia
}

\author{
Joydeep Bhattacharyya, William R. Walter, Megan P. Flanagan, \\ Jennifer O'Boyle and Michael E. Pasyanos \\ Geophysics and Global Security Division \\ Lawrence Livermore National Laboratory \\ P.O. Box 808, L-206, Livermore, CA 94551
}

\begin{abstract}
We present a regionalized crustal model of Western Eurasia, WEA. The model is constructed using results from published studies and maps of geological and geophysical parameters in this region, and was developed in conjunction with the updated regionalization of Middle East and North Africa by Walter et al. [2000]. As this is the first realization of our Eurasian modeling effort, we have limited ourselves to only twelve broad regions. Particular attention has been given to identifying the boundaries for each region. The main use of this model will be to assist in monitoring the Comprehensive Nuclear Test Ban Treaty (CTBT). Specifically, this model will help us to calibrate and predict the travel time and amplitudes of various regional seismic phases and to locate events accurately. Our model based approach allows us to readily calibrate both the seismic and the aseismic parts of western Eurasia. Each region is specified by an onedimensional model of compressional and shear velocities, densities and layer thicknesses. Further improvements to this model will involve, but not be limited to, increasing the spatial coverage toward the east and west of Eurasia, identify sub-regions based on their distinct physical properties and the use of new and improved body wave and surface wave datasets. In the future, we expect to use this model and its successors to be the baseline model for calibration techniques, e.g., kriging, to improve our capability to detect, locate and discriminate different seismic events in Eurasia.
\end{abstract}




\section{Introduction}

Knowledge of the propagation of seismic waves and accurate prediction of the seismic arrivals is an important component in monitoring the Comprehensive Nuclear Test Ban Treaty (CTBT). This allows us to properly locate, identify, and estimate the size of seismic event, thereby giving us the capability to discriminate an explosion from an earthquake. To do this, one important step is to calibrate the seismic properties, primarily the crust and mantle velocities, densities, and attenuation in our regions of interest. We develop a regionalized model of western Eurasia for this purpose. We call this model WEA; namely, the region between latitudes $50^{\circ} \mathrm{N}-85^{\circ} \mathrm{N}$ and longitudes $0^{\circ}-75^{\circ} \mathrm{E}$ are considered in current model WEA.

Typically, the classifications of small seismic events rely on regional data. To achieve the CTBT goal, the events need to be accurately located within a $1000 \mathrm{~km}^{2}$ region. So, it is important to construct robust models of crust and mantle structure that allows us to predict the arrival times and waveforms of the seismic phases at regional distances. Over the years, there have been several studies that have developed regionalized models of the crust and upper mantle globally. The earlier models developed by Flinn and Engdahl [1965] and Flinn et al. [1974] were based on seismicity and geographical features and are not adequate for seismic calibration. This was followed by several recent global regionalizations of the crust (Mooney et al. [1998]), the mantle (Nataf and Ricard [1996]; Gudmundsson and Sambridge [1998]) and the lithosphere (Jordan [1981]). Though these models were based on modern seismic data, they were too 
coarse (nominal resolution $5^{\circ}$ for the crustal models and $2^{\circ}$ for the mantle models) for modeling regional wave propagation. Therefore, construction of a regionalized model of Eurasia at finer grid spacing is needed. Recently, Du et al. [1998] developed a regionalized model of Europe. The lateral length scale of this model, $1^{\circ} \times 1^{\circ}$, is adequate for our seismic calibration. On the other hand, this model is predictive only at periods above 10 seconds and therefore not adequate for the high frequency body wave phases that constitute the bulk of our seismic arrival and waveform dataset. Also, this model covers only southern and western Europe and other parts of western Eurasia such as the Former Soviet Union, northern Scandinavia, the islands of Spitsbergen and Novaya Zemlya, are not accounted for. The recent 3-dimensional model by Ryaboy [1999] of northern Eurasia does cover much of these regions although the regionalization is based on variations of upper mantle structure. Therefore, structural boundaries in the crust, which can cause waveform complexities for regional phases, are not fully considered. This WEA model addresses these issues and lets us increase the coverage eastwards. Moreover, it provides a seamless transition to the MENA1.1 model of Walter et al. [2000] giving us an internally consistent model of the Middle East, North Africa and Western Eurasia.

To predict both body wave and short- and intermediate-period surface waves, we develop a preliminary set of seismically distinct regions where the primary attention has been given to delineating the boundaries. The model WEA has been developed using a synopsis of a priori models available in the literature. This approach is especially suitable for the analysis of large aseismic regions as it lets us extrapolate sparse calibration data, which lie within a similar geophysical region. The primary reasons for developing such a 
model is described in Sweeney and Walter [1998] and is briefly outlined here. First, using the three-dimensional seismic properties can improve our capability for seismic calibration. Second, tectonic boundaries, which can strongly affect the waveforms, will be properly delineated. Moreover, the spatial extent of distinct geophysical regions gives us estimates on the correlation lengths of our measurements. Finally, this model can provide a baseline for several avenues of future research, namely, discrimination, location and yield estimation, in Eurasia and eventually serve as a starting point for tomographic inversions.

WEA has been developed in conjunction with the model MENA1.1 (Walter et al. [2000]). Several of the regions are similar between the models and therefore, have the same crustal structure. We will first describe the parameterization of the model. Next we list the information sources that we have used to develop this model. The model regions, including their boundaries and seismic structures, are then described. Finally, using $P$ wave travel times, we validate the improvement we achieve in seismic calibration by using this model instead of the commonly used 1-dimensional model ak135 (Kennett et al. [1995]]).

\section{Model Parameterization}

The WEA is defined within the latitude limits of $50^{\circ} \mathrm{N}$ and $85^{\circ} \mathrm{N}$ and the longitude limits of $0^{\circ} \mathrm{E}$ and $75^{\circ} \mathrm{E}$ (Figure 1). The southern and eastern limits are chosen to be consistent with and complimentary to the MENA1.1 (Walter et al. [2000]). The western limit is chosen to include most of continental western Europe. Seismicity (using 
National Earthquake Information Center, NEIC, locations) and topography (using model ETOPO $^{1}$ ) of this region are also shown in Figure 1. We note that the region is mostly aseismic. The WEA model is presented in $1^{\circ} \times 1^{\circ}$ blocks and we consider that the seismic properties are uniform within each block. This is similar to the parameterization of Sweeney and Walter [1998] and is nominally chosen based on the nature of lateral variations in crustal structure and the lateral resolution of the seismic waves that will be calibrated. Large parts of western Eurasia are tectonically stable regions (e.g., Russian and Siberian platforms) and therefore the variations of crustal structure occur on length scales much larger than the $1^{\circ}$. On the other hand, we observe rapid structural variations in regions such as the North Caspian basin and the Trans European Suture Zone (TESZ) where finer scale parameterization is necessary. Each $1^{\circ} \times 1^{\circ}$ block is parameterized by up to seven layers: one water layer, two sedimentary layers (consolidated and unconsolidated), three crustal layers (upper, middle and lower) and an upper mantle layer. This format follows the model format of Mooney et al. [1998] and Sweeney and Walter [1998].

\section{Data Sources}

As mentioned earlier in the text, the geophysical regions are based on a priori models. The sources of information are as follows:

\footnotetext{
${ }^{1}$ Data Announcement 88-MGG-02, Digital relief of the Surface of the Earth. NOAA, National Geophysical Data Center, Boulder, Colorado, 1988.
} 
1. The tectonic map of the world developed by the Exxon corporation (Kaplan et al. [1985]).

2. The ETOPO5 digital topography and bathymetry map.

3. The gridded crustal model of velocities, densities and layer thicknesses, CRUST5.1, of Mooney et al. [1998].

4. A regionalized tectonic map of Asia and Eastern Europe developed by the United States Geological Survey (Terman and Alverson [1967]).

5. Global seismicity catalog obtained from the Lawrence Livermore National Laboratory (LLNL) seismic database. This catalog has been primarily developed using the seismicity reports of the National Earthquake Information Center (NEIC).

6. Several published reports on the crustal structures and tectonic boundaries of western Eurasia.

7. Results from active source experiments in western Eurasia. These results have also been used by Mooney et al. [1998] in their regionalization.

Recently, the seismic group in LLNL has undertaken several studies to document the seismic structure and wave propagation characteristics in western Eurasia. In the future, we plan to use results from these empirical datasets (e.g., surface wave dispersion, refraction seismic data, etc.) to improve on this model. Though seismicity is sparse in many parts of WEA (Figure 1), there have been several active seismic surveys in this region. Several of the earlier surveys have used large sources such the Peaceful Nuclear Explosions, PNE's (Solodilov [1997]; Fuchs and Wenzel [1997]; Schueller et al. [1997]; Morozova et al. [1999]). The location and geometry of these profiles make them ideal for 
resolving the crust and mantle structures of the stable platforms of eastern Europe (Nielsen et al. [1999]; Ryberg et al. [1996]; and many others). On the other hand, several recent experiments in Eurasia (e.g., EUROPROBE, URALSEIS, VARNET, MONA LISA, BABEL, POLONAISE) traverse tectonic boundaries and are therefore ideal for defining these boundaries. Mooney et al. [1998] have used results from several of these studies and therefore the crustal properties given in their model CRUST5.1 are considered to be representative; we use small modifications of these models for most of the regions in WEA. Additionally, the $1^{\circ} \times 1^{\circ}$ parameterization used for WEA give us greater flexibility to define the shape of the tectonic boundaries accurately.

\section{Brief description of the Seismically Distinct Regions}

We divide western Eurasia into twelve geophysically distinct regions (Figure 2) which vary in size and are classified according to broad tectonic themes. To simplify our model, we choose only a small number of distinct units disregarding some of the secondary tectonic features (e.g., basins) within each of the regions. The sedimentary layer thickness and/or upper mantle structure primarily distinguish many of these units. Fortunately, higher resolution models of the sediment layer (Laske and Masters [1997]) and the upper mantle (Gudmundsson and Sambridge [1998]) are available which will be incorporated into our model in the future. Below, we present a brief description of the models that have primarily been derived from the CRUST5.1 model of Mooney et al. [1998]. The models are presented in Table 1. Probable subdivisions of each of these 
regions are also discussed. As in Mooney et al. [1998], we use a mantle $V_{p} / V_{s}$ ratio of 1.77 .

Region 1. Oceanic Crust

This region has primarily been developed based on bathymetry and sediment thickness and contains parts of the Arctic and the North Atlantic Oceans. We also separate the seismically active ridges from within this region and identify them as region 12. Most of this region falls under the models for "normal oceanic crust" which differ primarily in their sediment thickness. Our Region 1 does not belong to any active subduction zones or deep basins and therefore has a typically thin sedimentary cover. We choose the model A2 for this region which is consistent with the oceanic region 1 of Walter et al. [2000]. In the future, we will likely adopt an oceanic crustal structure which varies with age (Zhang and Lay [1999]).

\section{Region 2. Continental Shelf}

The continental shelf region lies between the northern boundary of continental Eurasia and the deep ocean; this region is expected to have thick sedimentary cover. Moreover, the crustal structure of the Barents and the Kara Seas are expected to be similar to the structures of the adjacent Russian and West Siberian Platforms respectively. The crust within the Barents Sea is about $30-36 \mathrm{~km}$ thick (Breivik et al. [1998]). This region consists of model C3 - C6 of Mooney et al. [1998] though most of it is covered with region $\mathrm{C} 5$. We choose $\mathrm{C} 5$ for this region as it is distinct from the oceanic crust (Region 1) by having a large crustal thickness $(=32 \mathrm{~km})$ and from the continental 
crust in having a thick sedimentary layer $(=5.5 \mathrm{~km})$. It also has a high $P n$ velocity of 8.2 $\mathrm{km} / \mathrm{s}$. This region consists of several provinces of thick sediments though they have a similar tectonic history. The Barents and the Kara Seas contain several deep basins (Ostisty and Cheredeev [1993]) which may be separated into a new region in the future. These basins can effect seismic wave propagation; for instance, Baumgardt [1990] has shown that the thick sedimentary basins in the southern Barents Sea can significantly block $L g$ waves. Such propagation characteristics have been catalogued by Zhang and Lay [1994] for explosions at Novaya Zemlya and are important for CTBT monitoring.

\section{Region 3. Norwegian Sea}

The Norwegian sea consists primarily of extended continental crust and is Mesozoic and Cenozoic in origin. This region is continental in origin and thus has a low velocity in the upper crystalline crust and normal Poisson's ratio (Mjelde et al. [1997]; Mjelde et al. [1998]; Digranes et al. [1998]). Mjelde et al. [1998] approximated an average lower crust velocity of $7.2 \mathrm{~km} / \mathrm{s}$ in this region and Mjelde et al. [1997] estimated the $P n$ velocity in the Vøring basin of this region to be about $8.2 \mathrm{~km} / \mathrm{s}$. This region corresponds to the model Y6 of Mooney et al. [1998] with a $21.5 \mathrm{~km}$ thick crust; we adopt this structure. The crustal thickness is also consistent with the results from gravity and magnetic data (Fichler et al. [1999]). This region has a slightly greater crustal thickness and higher upper and middle crustal velocities compared to a normal oceanic crust. There is an evidence for high $V p / V s$ in this region (Digranes et al. [1998]) and we might need to change the shear-wave velocities in the future. 


\section{Region 4. Baltic Shield}

This region consists of the Scandinavian countries and the Northern Baltic sea. The Baltic shield is mostly Early- to Middle-Proterozoic and is expected to have a thick crust. The Paleozoic orogenic belt in Norway is included in this region as its deep crustal structure is expected to be similar to the Baltic shield. The southern boundary of this region coincides with the Tornquist-Tesseyre Zone, TTZ, and its northern extension, the Sorgenfrei-Tornquist Zone, STZ. We call this boundary TTZ for short. The TTZ is usually referred to as the boundary between the Precambrian crystalline crust of the Baltic Shield and the Russian Platform and the younger crust of central Europe and the 3dimensional S-velocity model of Zielhuis and Nolet [1994] and the density model of Yegorova and Starosenko [1999] reveals that below this line a sharp lateral boundary extends down to at least $140 \mathrm{~km}$ depth. Schweitzer [1995] has shown clearly the influence of the TTZ on regional wave propagation. Lie and Andersson [1998] and Tryggvason et al. [1998] have inferred, following analyses of deep seismic profiles, that this Scandinavian section of the Tornquist zone represents a boundary between the thick crust of the Baltic sea and the thinner basin crystalline crust of central Europe. CRUST5.1 predicts the model $\mathrm{H} 2$ for most of the Baltic shield; we adopt this model for the region. However, in the future we may need to delineate the thick shield (=50 km crust) in Finland (Pilipenko et al. [1999]; Väino and Flodén [1999]) and the younger Caledonides orogenic belt in Andersen [1998]) as separate regions. The Murmansk Shear Zone in the northeastern part marks as a terrane boundary (Roberts et al. [1997]) and might be used for further subdivision of this region. 


\section{Region 5. Western European Extended Crust}

This region is defined by the TTZ to the north and east, the North sea to the northwest and the foreland basins related to the alpine orogeny to the south coinciding with Region 28 of Sweeney and Walter [1998]. Region 5 consists of several terrains including thin basins south of the TTZ and the orogenic belts of the Harz and the Jura mountains. CRUST5.1 for this region consists of extended crust with types N1, N2 and N3 with a relatively thin $31 \mathrm{~km}$ crust. The orogenic regions belong to the P2 (Alps foreland) crustal type that has a relatively thick upper and middle crust. We adopt the model $\mathrm{N} 2$ for this region and the middle crust is increased by $2 \mathrm{~km}$ to account for the orogenic regions giving a total crustal thickness of $33 \mathrm{~km}$. In the future, we expect to subdivide this region into its basins and orogenic belts. For instance, the crustal thickness in the North German Basin is only about $25 \mathrm{~km}$ thick (Tryggvason et al. [1998]).

\section{Region 6. Russian Platform}

The Early Proterozoic Russian platform is defined by the stable Baltic shield to the west, the orogenic belts of TTZ and the Urals to the west and east respectively and by thick sedimentary basins (Caspian and Uralian foredeeps) to the southeast. The Mooney model for this region is D6; we choose this model and to be consistent with the region 23 of Walter et al. [2000]. This model generally agrees with the average model presented by the EUROBRIDGE group for the central portion of this platform (Doody et al. [1999]). There are several deep sedimentary basins in this region, e.g., Moscow, Dnieper-Donets, Pripyat, Pachelma, etc. and the deeper Uralian foredeep (Zonenshain et al. [1984]; Lobkovsky et al. [1996]; Ilchenko [1997]; Stovba et al. [1997]; Kostyuchenko et al. 
[1999]), which we will account for in the future using the sediment model of Laske and Masters [1997]. These sedimentary basins are important for explaining regional wave propagation. For instance, Baumgardt [1990] has shown that the Ural foredeep basin can cause blockage and scattering for $L g$ waves. The Ukrainian shield located in the southwest part of this region has a thicker crust, less sedimentary cover, and faster $P n$ velocity compared to the model D6 (Grad and Tripolsky [1995]; Pavlenkova [1996]) and might also need to be identified as a separate region in the future. The southwest Baltic Sea might have to be demarcated as a separate region as it has been shown to have a thin crust $(\approx 30 \mathrm{~km})$ with low crustal velocities compared to the rest of the Russian platform (Bleibinhaus et al. [1999]). Small changes might also be required for the southwestern part of this region where anomalously low $V p / V s$ ratio of 1.67 and a low $P n$ velocity of $8.1 \mathrm{~km} / \mathrm{s}$ has been recently reported (Sroda and group [1999]).

\section{Region 7. North Caspian Depression}

This region has some of the deepest basement depths, up to $20 \mathrm{~km}$ deep according to a sediment thickness map of this region (Brunet et al. [1999]). The CRUST5.1 model uses the crust type $\mathrm{Y} 7$ for this region which, because of averaging inside a $5^{\circ}$ block, has only $12 \mathrm{~km}$ of sediments. To account for the thicker sediment layer, we add an additional consolidated sediment layer $\left(\mathrm{V}_{\mathrm{p}}=6.0 \mathrm{~km} / \mathrm{s}\right)$ for this region giving us a crustal thickness of $41 \mathrm{~km}$. We adjust the boundaries to be consistent with those of Region 20 in MENA1.1. Brunet et al. [1999] have shown clear variations of basement thickness across this region which we account for in the future using the sediment thickness map of Laske 
and Masters [1997]. Moreover, the crustal thickness reduces to about $30 \mathrm{~km}$ in the central part of the depression which will be considered in the future.

Region 8. Ural Mountains

This region forms a tectonic boundary between the Precambrian Russian platform to the west and the Paleozoic west Siberian platform to the east. The boundary of this region has been primarily drawn based on topography (from ETOPO5) and the rock ages as given in the Exxon map. We have extended the northern boundary offshore to include the island of Novaya Zemlya as it has a similar genesis. The southern boundary of Region 10 joins up with Region 29 of MENA1.1. In CRUST5.1, this region primarily consists of crustal types P1 and P4. Levin and Park [1997] and Levin et al. [1999] have carried out a receiver function study of the station ARU, which lies in the Uralian foredeep, and have reported a thin crust of $40 \mathrm{~km}$. We therefore choose the model with the thinner crust, i.e., P1. Also, to account for the sedimentary basins to the north, we double the sedimentary thickness of this model to $4 \mathrm{~km}$. Juhlin et al. [1998] and [Knapp et al. [1998]] have shown that, on average, the crust in the Urals thickens from about $45 \mathrm{~km}$ in the flanks to about $51 \mathrm{~km}$ towards the central axis. Thus, our estimate of a $48 \mathrm{~km}$ thick crust is an appropriate average, though we might have to segment the different regions within the Urals in the future.

There have been several active source profiles running across the Urals, e.g., ESRU, URALIDES, URSEIS, QUARTZ, RUBY, GRANIT, giving us high resolution insights of the Uralian crust and upper mantle (Thouvenot et al. [1995]; Berzin et al. [1996]; Juhlin et al. [1996]; Juhlin et al. [1998]; Knapp et al. [1998]; Steer et al. [1998]). 
The Uralide orogen marks the Paleozoic collision zone of the East European Craton with the with the platforms in northwestern Asia. This collision has caused crustal thickening, and uniquely, this is one of the very few places in the world where the thickened crust is intact (Kerr [1996]). This gives rise to the most significant feature of the Ural mountains: its deep crustal root. Estimates of the crustal root vary along strike within the orogen (Knapp et al. [1998]); for instance, in the middle Urals it can be as high as $55-60 \mathrm{~km}$ thick with a $P n$ velocity of $8.5 \mathrm{~km} / \mathrm{s}$ (Thouvenot et al. [1995]; Berzin et al. [1996]; Knapp et al. [1996]; Druzhinin et al. [1997]).

\section{Region 9. Kazakh Uplands}

The Kazakh Uplands region is located in the northern parts of the Kazakh fold system that is an active orogenic belt. This region has a thin sedimentary cover of about 1 $\mathrm{km}$. CRUST5.1 has the model D9 in this region and we choose it as well. This model has $41 \mathrm{~km}$ crust and is consistent with Region 21 in MENA1.1. The crustal thickness estimate of this model might need to be adjusted in the future. Ryaboy [1989] has shown that the crustal thickness in this region ranges between $45-55 \mathrm{~km}$. Quin and Thurber [1992] have modeled regional $P$-waves in Kazakhstan and have estimated a crustal thickness of $50 \mathrm{~km}$ with a $P n$ velocity gradient between $8.05-8.25 \mathrm{~km} / \mathrm{s}$ in the uppermost $5 \mathrm{~km}$ of the mantle.

\section{Region 10. West Siberian Platform}

This Paleozoic platform is largely aseismic and very little is known about its crustal structure. Most of what we know of this region have been derived from active 
source experiments (Pavlenkova [1996]). Based on these results, Mooney et al. [1998] primarily chose the model DB for this region; we adopt this model for our Region 10. This model has a crustal thickness of $41 \mathrm{~km}$ which is consistent with the average value in this region (Aplonov [1995]). In the future, the thick sedimentary basin in the northeastern part of this region (Aplonov [1995]) might need to be identified as a separate region. In future improvements of WEA, we will most probably extend the eastern boundary of this region to the Paleozoic - Proterozoic boundary in Central Siberia. Results from surface wave tomography and the analysis of the several PNE data that traverse this region (KRATON, KIMBERLITE, METEORITE) can be used to improve this crustal model.

\section{Region 11. North Sea}

The North Sea has a significantly thicker sedimentary layer (Exxon maps) and crust compared to the adjacent Norwegian Sea and the Atlantic Ocean. This region corresponds to the Eastern Avalonia plate. We follow CRUST5.1 in choosing model C4 for this region which has a crustal thickness of $32 \mathrm{~km} .$. Recently, Abramovitz et al. [1999] have observed crustal thinning $(=26 \mathrm{~km})$ in the northern part of this region; we will investigate this model with seismic data in the future.

\section{Region 12. Ocean Ridges}

This region primarily consists of the Mohn ridge which has been identified based on the classification given by the model MENA1.1 and is needed to account for the slow oceanic ridges (Pasyanos et al. [2000]; Ritsema and van Heijst [2000]). As described in 
Walter et al. [2000], we used bathymetry and seismicity to demarcate the ocean ridges. We used a modified version of structure A0 of Mooney et al. [1998] for this region that is consistent with the region 1A of MENA1.1.

\section{Geocoding and registration of region boundaries}

For the use of future analysis of and using the WEA model, we have geo-coded the boundaries of the twelve regions. This has been done in conjunction with the creation of the MENA1.1 model of Walter et al. [2000]. We have used a GIS system to register each $1^{\circ} \times 1^{\circ}$ block with its region number. The gridded model is shown in Figure 3. Most important, it gives a 3-dimensional grid of seismic parameters that can be used for computing body- and surface-wave predictions (waveforms and amplitudes) and gives us the regional basis functions for the inversion of seismic data. Secondly, we can incorporate information from other geo-registered maps to improve this model. For instance, we have overlaid the WEA model on the EXXON map (Figure 4). This allows us to improve the locations of the boundaries, especially ones that were based on sediment contours and rock types, i.e., Regions 7 and 8 . Finally, this block model lets us analyze each region separately and re-digitize them at different grid spacing.

\section{Conclusions and future improvements to the WEA model}

WEA has been developed as a part of the LLNL initiative to generate a priori 3dimensional models. The first of these is MENA1.0 of Sweeney and Walter [1998] that 
has evolved to an updated MENA1.1 model (Walter et al. [2000]) which complements our study. WEA is defined in every $1^{\circ} \times 1^{\circ}$ block though the layer parameters (thickness, velocity, density) are the same for blocks within the same region. Moreover, this model is based completely on published models and is truly a priori; we have not analyzed seismic data ourselves to refine or alter this model. In our improvements to this model, we will use the following information:

1) The eastern boundary of WEA, $75^{\circ} \mathrm{E}$, has been adopted to be consistent with the MENA1.1. In the future, we will expand this eastwards to include the Kuriles and the Kamchatka peninsula, i.e., to about $170^{\circ} \mathrm{E}$.

2) Recently, Laske and Masters [1997] have developed a global basement model with distinct structures for every $1^{\circ}$ block. This model consists of three layers for each block though, obviously, in many blocks one or several of the layers have zero thickness. We will use this model to update the sedimentary layer(s) of WEA.

3) An accurate model of the upper mantle seismic structure is critical in predicting regional seismic data. We will use a recently developed upper mantle model, RUM (Gudmundsson and Sambridge [1998]), to estimate the structure at fixed depths below WEA.

4) Seismic models and datasets currently being archived by our group at LLNL will be used to refine the model parameters, identify geophysically distinct regions and modify the region boundaries.

5) Test and validate the WEA model in different geographic areas and recommend improvements based on how well the model predicts observations of travel times, surface wave phase and group velocities, etc.. We have recently developed a three- 
dimensional travel time calculator which uses a finite difference approximation. A residual time is computed by subtracting the predicted travel times from observed data archived at LLNL. These times can be used to generate station specific correction surfaces which will let us identify regions where the WEA model needs to be improved.

6) Large regions covered by our model are largely aseismic and therefore the validation of regional waves is difficult using earthquakes only. To mitigate this problem, we have archived data from several Soviet PNE shots giving us a ground-truth dataset with exceptional coverage of the aseismic regions. Once validated, this model can be used to improve our ability to locate seismic events compared to those using 1-D global models.

The results of these improvements will be published in future reports.

\section{Acknowledgements}

We thank Bill Leith, Walter Mooney and Jerry Sweeney with helping us resolve the tectonic boundaries and also in making available to use several references on Eurasian crustal structure. This work was performed under the auspices of the U.S. Department of Energy by University of California Lawrence Livermore National Laboratory, under contract No. W-7405-Eng-48. 


\section{Bibliography}

Abramovitz, T., M. Landes, H. Thybo, A.W.B. Jacob, and C. Prodehl, Crustal velocity structure across the Tornquist and Iapetus suture zones - a comparison based on MONA LISA and VARNET data, Tectonophysics, 314, 69 - 82, 1999.

Andersen, A.B., Extensional tectonics in the Caledonides of southern Norway, an overview, Tectonophysics, 285 , 333 - 351, 1998.

Aplonov, S.V., The tectonic evolution of west Siberia: an attempt at a geophysical analysis, Tectonophysics, 245 , 61 - 84, 1995.

Baumgardt, D.R., Investigation of teleseismic $L g$ blockage and scattering using regional arrays, Bull. Seismol. Soc. Am., 80, 2261- 2281, 1990.

Berzin, R., O. Oncken, J.H. Knapp, A. Perez-estaun, T. Hismatulin, N. Yunusov, and A. Liplin, Orogenic evolution of the Ural mountains; results from an integrated seismic experiment, Science, 274, 220 - 221, 1996.

Bleibinhaus, F., T. Beilecke, K. Bram, and H. Gebrande, A seismic velocity model for the SW Baltic Sea derived from BASIN'96 refraction seismic data, Tectonophysics, 314, 269 - 283, 1999.

Breivik, A.J., J.I. Faleide, and S.T. Gudlaugsson, Southwestern Barebts Sea margin: late Mesozoic sedimentary basins and crustal extension, Tectonophysics, 293, $21-44,1998$.

Brunet, M.F., Y.A. Volozh, M.P. Antipov, and L.I. Lobkovsky, The geodynamic evolution of the Precaspian Basin (Kazakhstan) along a north-south section, Tectonophysics, 313, 85 - 106, 1999. 
Digranes, P., R. Mjelde, S. Kodaira, H. Shimamura, T. Kanazawa, H. Shiobara, and E.W. Berg, A regional shear-wave velocity model in the central Vøring basin, N. Norway, using three-component Ocean Bottom Seismographs, Tectonophysics, 293,157 - 174, 1998.

Doody, J.J., R. Giese, M. Grad, and H. Thybo, Seismic velocity structure across the Fennoscandia - Sarmatia suture of the East European Craton beneath the EUROBRIDGE profile through Lithuania and Belarus, Tectonophysics, 314 , $193-217,1999$.

Druzhinin, V.S., S.N. Kashubin, T.V. Kashubina, V.A. Kolmogorova, G.V. Parygin, A.V. Rybalka, and A.M. Tiunova, The main features of the interface between the crust and the upper mantle in the middle Urals (in the vicinity of the deep drillhole SG-4), Tectonophysics, 269 , 259 - 267, 1997.

Du, Z.J., A. Michelini, and G.F. Panza, Eur1D: a regionalized 3-D seismological model of Europe, Phys. Earth Planet. Int., 106,31 - 62, 1998.

Fichler, C., E. Rundhovde, O. Olesen, B.M. Sæther, H. Rueslåtten, E. Lundin, and A.G. Doré, Regional tectonic interpretation of image enhanced gravity and magnetic data covering the mid-Norwegian shelf and adjacent mainland, Tectonophysics, 306,183 - 197, 1999.

Flinn, E.A., and E.R. Engdahl, A proposed basis for geographical and seismic regionalization, Rev. Geophys., 3, 123 - 149, 1965.

Flinn, E.A., E.R. Engdahl, and A.R. Hill, Seismic and geographical regionalization, Bull. Seismol. Soc. Am., 64, 971 - 992, 1974. 
Fuchs, K., and F. Wenzel, Conservation of lithospheric DSS-data, in Upper mantle heterogeneities from active and passive seismology, edited by K. Fuchs, pp. 11 - 31, Kluwer Academic Publishers, 1997.

Grad, M., and A. A. Tripolsky, Crustal structure from $P$ and $S$ seismic waves and petrological models of the Ukrainian shield, Tectonophysics, 250, 89 - 112, 1995.

Gudmundsson, O., and M. Sambridge, A regionalized upper mantle (RUM) seismic model, J. Geophys. Res, 103, 7121 - 7136, 1998.

Ilchenko, T., Dniepr - Donets Rift: deep structure and evolution from DSS profiling, Tectonophysics, 268, 93 - 98, 1997.

Jordan, T., Global tectonic regionalization for seismological data analysis, Bull. Seismol. Soc. Am., 71, 1131 - 1141, 1981.

Juhlin, C., M. Friberg, H.P. Echtler, T. Hismatulin, A. Rybalka, A.G. Green, and J. Ansorge, Crustal structure of the middle Urals: results from the (ESRU) Europrobe seismic reflection profiling in the Urals experiments, Tectonics, 17, $710-725,1998$.

Juhlin, C., J.H. Knapp, S. Kashubin, and M. Bliznetsov, Crustal evolution of the middle Urals based in seismic reflection and refraction data, Tectonophysics, $264,21-34,1996$.

Kaplan, A., C.U. Lusser, and I.O. Norton, Tectonic Map of the World, Exxon Research Company, 1985.

Kennett, B. L. N., Engdahl, E. R., and Buland, R, Constraints on seismic velocities in the Earth from travel-times, Geophys. J. Int., 122, 108-124, 1995. 
Kerr, R., Urals yield secret of a lasting bond, Science, 274 , 181, 1996.

Knapp, J.H., C.C. Diaconescu, M.A. Bader, V.B. Sokolov, S.N. Kashubin, and A.V. Rybalka, Seismic reflection fabrics of continental collision and postorogenic extension in the Middle Urals, central Russia, Tectonophysics, 288, 115 - 126, 1998.

Knapp, J.H., D.N. Steer, L.D. Brown, R. Berzin, A. Suleimanov, M. Stiller, E. Luschen, D.L. Brown, R. Bulgakov, S.N. Kashubin, and A. Rybalka, Lithosphere scale seismic image of the southern Urals from explosion source reflection profiling, Science, 274 , 226 - 228, 1996.

Kostyuchenko, S.L., A.V. Egorkin, and L.N. Solodilov, Structure and genetic mechanisms of the Precambrian rifts of the East-European platform in Russia by integrated study of seismic, gravity and magnetic data, Tectonophysics, 313, 9 28, 1999.

Laske, G., and T.G. Masters, A global digital map of sediment thickness, EOS Trans, suppl, 78, F483, 1997.

Levin, V., W. Menke, and J. Park, Shear-wave splitting in Appalachians and Urals: a case for multilayered anisotropy, J. Geophys. Res, 104 , 17975-17994, 1999.

Levin, V., and J. Park, Crustal Anisotropy in the Ural Mountains foredeep from teleseismic receiver functions, Geophys. Res. Lett., 24 , 1283-1286, 1997.

Lie, J.E., and M. Andersson, The deep-seismic image of the crustal structure of the Tornquist zone beneath the Skagerrak Sea, northwestern Europe, Tectonophysics, 287, 139 - 155, 1998. 
Lobkovsky, L.I., S. Cloetingh, A.M. Nikishin, Y.A. Volozh, A.C. Lankreijer, S.L. Belyakov, V.G. Groshev, P.A. Fokin, E.E. Milanovsky, L.A. Pevzner, V.I. Gorbachev, and M.A. Korneev, Extensional basins of the former Soviet Union structure, basin formation mechanisms and subsidence history, Tectonophysics, $266,251-285,1996$.

Mjelde, R., P. Digranes, H. Shimamura, H. Shiobara, S. Kodaira, H. Brekke, T. Egebjerg, N. Sørenes, and S. Thorbjørnsen, Crustal structure of the northern part of the Vøring basin, mid-Norway margin, from wide angle seismic and gravity data, Tectonophysics, $293,175-205,1998$.

Mjelde, R., S. Kodaira, H. Shimamura, T. Kanazawa, H. Shiobara, E.W. Berg, and O. Ruuse, Crustal structure of the central part of the Vøring basin, midNorway margin, from ocean bottom seismographs, Tectonophysics, 277, 235 257, 1997.

Mooney, W.D., G. Laske, and T.G. Masters, CRUST5.1: a global crustal model at $5^{\circ}$ X 5, J. Geophys. Res, $103,727-747,1998$.

Nataf, H.-C., and Y. Ricard, 3SMAC: an a priori tomographic model of the upper mantle based on geophysical modeling, Phys. Earth. Planet. Int., 95 , 101 122, 1996.

Nielsen, L., H. Thybo, and L. Solodilov, Seismic tomographic inversion of Russian PNE data along profile KRATON, Geophys. Res. Lett., 26, 3413 - 3416, 1999. 
Ostisty, B.K., and S.I. Cheredeev, Main factors controlling regional oil and gas potential in the West Arctic, former USSR, in Basin Modeling: Advances and Applications, edited by A.G. Doré, pp. 591-597, Elsevier, Amsterdam, 1993.

Pasyanos, M.E., W.R. Walter, and S.E. Hazler, A surface wave dispersion study of the Middle East and North Africa for Monitoring the Comprehensive Nuclear Test Ban treaty, Pageoph., In Press , 2000.

Pavlenkova, N.L., Crust and upper mantle structure in Northern Eurasia from Seismic Data, Adv. Geophys., 37 , 1-134, 1996.

Pilipenko, V.N., N.I. Pavlenkova, and U. Luosto, Wide-angle reflection migration technique with an example from the POLAR profile (northern Scandinavia), Tectonophysics, 308 , 445 - 457, 1999.

Quin, H.R., and C.H. Thurber, Seismic velocity structure and event relocation in Kazakhstan from secondary $P$ phases, Bull. Seismol. Soc. Am., 82 , 2494 $2510,1992$.

Ritsema, J., and H. van Heijst, New seismic model of the upper mantle beneath Africa, Geology, 28, 63 - 66, 2000.

Roberts, D., O. Olesen, and R. Karpuz, Seismo- and neotectonics in Finnmark, Kola Peninsula and the southern Barents Sea. Part 1: Geological and neotectonic framework, Tectonophysics, 270, 1 - 13, 1997.

Ryaboy, V.a.o., Development of 3-D crustal and upper mantle velocity models of Northern Eurasia and North America to refine location of regional seismic events, in 21st Seismic Research Symposium, pp. 616 - 625, Las Vegas, USA, 1999. 
Ryaboy, V.Z., Upper mantle structure studies by explosion seismology in the USSR, pp. 54, DELPHIC Associates, Arlington, VA, 1989.

Ryberg, T., F. Wenzel, J. Mechie, A. Egorkin, K. Fuchs, and L. Solodilov, Two-dimensional velocity structure beneath northern Eurasia derived from the super-long range seismic profile Quartz, Bull. Seismol. Soc. Am., 86, 857 - 867, 1996.

Schweitzer, J., Blockage Of Regional Seismic-Waves By the TeisseyreTornquist Zone, Geophys. J. Int., 123, 260-276, 1995.

Solodilov, L.N., The GEON center: 25 years of implementation of PNE in studies of earth's deep structure, in Upper mantle heterogeneities from active and passive seismology, edited by K. Fuchs, pp. 1 - 10, Kluwer Academic Publishers, 1997.

Sroda, P., and P.p.P.w. group, $P$ - and $S$-wave velocity model of the southwestern margin of the Precambrian East European Craton; POLONAISE'97, profile P3, Tectonophysics, 314 , 175 - 192, 1999.

Steer, D.N., J.H. Knapp, L.D. Brown, H.P. Echtler, and R. Berzin, Deep structure of the continental lithosphere in an unextended orogen: an explosive source seismic reflection profile in the Urals, Tectonics, 17,143 - 157, 1998.

Stovba, S., R.A. Stephenson, and M. Kivshik, Structural features and evolution of the Dniepr - Donets basin, Ukraine, from regional seismic reflection profiles, Tectonophysics, 268,127 - 147, 1997. 
Sweeney, J., and W.R. Walter, Preliminary definition of geophysical regions for the Middle east and North Africa, pp. 38, Lawrence Livermore National Laboratory, UCRL-ID-132899, Livermore, 1998.

Terman, M.J., and D.C. Alverson, Atlas of Asia and Eastern Europe, U. S. Geological Survey, 1967.

Thouvenot, F., S.N. Kashubin, G. Poupinet, V.V. Makovsky, T.V. Kashubina, P. Matte, and L. Jenatton, The root of the Urals: evidence form wide angle reflection seismics, Tectonophysics, 250, 1 - 13, 1995.

Tryggvason, A., C.-E. Lund, and M. Friberg, A two-dimensional seismic velocity model across the transition zone between the Baltic shield and the North German Basin - the EUGENO-S profile 1 revisited, Tectonophysics, 290, 47 - 58, 1998.

Väino, P., and T. Flodén, Rapakivi-granite-anorthosite magmatism - a way of thinning and stabilization of the Svecofennian crust, Baltic Sea basin, Tectonophysics, 305,75 - 92, 1999.

Walter, W.R., M.E. Pasyanos, J. Bhattacharyya, and J. O'Boyle, MENA1.1 an updated geophysical regionalization of the Middle East and North Africa, Lawrence Livermore National Laboratory, Livermore, 2000.

Yegorova, T.P., and V.I. Starosenko, Large-scale three-dimensional gravity analysis of the lithosphere below the transition zone from Western Europe to the East European Craton, Tectonophysics, 314, 83 - 100, 1999. 
Zhang, T., and T. Lay, Effects of crustal structure under the Barents and Kara seas in short-period regional wave propagation for Novaya Zemlya explosions: empirical relations, Bull. Seismol. Soc. Am., 84 , 1132 - 1147, 1994.

Zhang, Y.S., and T. Lay, Evolution of oceanic upper mantle structure, Phys. Earth Planet. Int., 114,71 - 80, 1999.

Zielhuis, A., and G. Nolet, Shear-Wave Velocity Variations In the UpperMantle Beneath Central-Europe, Geophys. J. Int., 117, 695-715, 1994.

Zonenshain, L.P., V.G. Korinevsky, V.G. Kazmin, D.M. Pechersky, V. Khain, and V.V. Matveenkov, Plate tectonic model of the South Urals development, Tectonophysics, 109 , 95-135, 1984. 


\section{Table 1. Velocity Models}

Velocity models for geophysical regions. Depths are in kilometers, velocities are in $\mathrm{km} / \mathrm{s}$ and densities are in gm/cc. The models are based on CRUST5.1 of Mooney et al. [1998] and are described in the text. The reference Mooney model is noted, and a '*' indicates that the Mooney model has been modified.

\begin{tabular}{cccl} 
Region 1 & \multicolumn{4}{c}{ CRUST5.1 A2* } \\
Depth & Vp & Vs & Density \\
\hline & & & \\
0.00 & 1.50 & 0.00 & 1.02 \\
5.00 & 2.10 & 0.90 & 2.10 \\
6.00 & 5.00 & 2.50 & 2.60 \\
7.70 & 6.60 & 3.65 & 2.90 \\
10.00 & 7.10 & 3.90 & 3.05 \\
12.50 & 8.15 & 4.61 & 3.40
\end{tabular}

\begin{tabular}{cccc} 
Region 2 & \multicolumn{3}{c}{ CRUST5.1 C5 } \\
Depth & Vp & Vs & Density \\
\hline & & & \\
0.00 & 1.50 & 0.00 & 1.02 \\
1.00 & 2.30 & 1.10 & 2.20 \\
3.00 & 3.20 & 1.60 & 2.30 \\
6.50 & 6.00 & 3.40 & 2.70 \\
15.00 & 6.60 & 3.70 & 2.90 \\
24.00 & 7.20 & 4.00 & 3.10 \\
32.00 & 8.20 & 4.63 & 3.40
\end{tabular}

\begin{tabular}{cccl} 
Region 3 & \multicolumn{3}{c}{ CRUST5.1 Y6 } \\
Depth & Vp & Vs & Density \\
\hline & & & \\
0.00 & 1.50 & 0.00 & 1.02 \\
1.00 & 2.30 & 1.10 & 2.20 \\
3.00 & 6.00 & 3.40 & 2.70 \\
9.00 & 6.60 & 3.70 & 2.90 \\
15.00 & 7.20 & 4.00 & 3.05 \\
21.50 & 8.15 & 4.60 & 3.40
\end{tabular}




\begin{tabular}{cccc} 
Region 4 & \multicolumn{3}{l}{ CRUST5.1 H2 } \\
Depth & Vp & Vs & Density \\
\hline & & & \\
0.00 & 6.20 & 3.60 & 2.80 \\
15.00 & 6.60 & 3.70 & 2.90 \\
31.00 & 7.10 & 3.90 & 3.05 \\
45.00 & 8.20 & 4.63 & 3.40
\end{tabular}

\begin{tabular}{cccc} 
Region 5 & \multicolumn{4}{l}{ CRUST5.1 N2* } & \\
Depth & Vp & Vs & Density \\
\hline & & & \\
0.00 & 2.50 & 1.10 & 2.10 \\
1.00 & 5.00 & 2.90 & 2.50 \\
2.00 & 6.10 & 3.50 & 2.75 \\
11.00 & 6.30 & 3.60 & 2.80 \\
23.00 & 6.60 & 3.60 & 2.90 \\
33.00 & 8.00 & 4.52 & 3.35
\end{tabular}

\begin{tabular}{cccc} 
Region 6 & CRUST5.1 D6 & \\
Depth & Vp & Vs & Density \\
\hline & & & \\
0.00 & 2.50 & 1.10 & 2.10 \\
0.50 & 4.00 & 2.10 & 2.40 \\
2.00 & 6.20 & 3.60 & 2.80 \\
17.00 & 6.60 & 3.70 & 2.90 \\
32.00 & 7.30 & 4.00 & 3.10 \\
41.00 & 8.20 & 4.63 & 3.40
\end{tabular}

\section{Region 7 CRUST5.1 Y7*}

\begin{tabular}{llll} 
Depth & Vp & Vs & Density \\
\hline
\end{tabular}

$\begin{array}{cccc}0.00 & 2.50 & 1.10 & 2.10 \\ 1.00 & 4.00 & 2.10 & 2.40 \\ 12.00 & 6.00 & 3.40 & 2.70 \\ 17.00 & 6.60 & 3.70 & 2.90 \\ 29.00 & 7.10 & 3.90 & 3.05 \\ 41.00 & 8.15 & 4.60 & 3.40\end{array}$


Region 8 CRUST5.1 P1*

$\begin{array}{llll}\text { Depth Vp Vs Density } & \end{array}$

$\begin{array}{cccc}0.00 & 2.50 & 1.10 & 2.10 \\ 2.00 & 4.00 & 2.10 & 2.40 \\ 4.00 & 6.10 & 3.50 & 2.75 \\ 24.00 & 6.30 & 3.60 & 2.80 \\ 44.00 & 7.20 & 4.00 & 3.10 \\ 48.00 & 8.00 & 4.52 & 3.35\end{array}$

Region 9 CRUST5.1 D9

$\begin{array}{llll}\text { Depth Vp Vs Density } & \end{array}$

$\begin{array}{cccc}0.00 & 2.50 & 1.10 & 2.10 \\ 0.50 & 4.00 & 2.10 & 2.40 \\ 1.00 & 6.20 & 3.60 & 2.80 \\ 17.00 & 6.60 & 3.70 & 2.90 \\ 32.00 & 7.30 & 4.00 & 3.10 \\ 41.00 & 8.20 & 4.63 & 3.40\end{array}$

Region 10 CRUST5.1 DB

$\begin{array}{llll}\text { Depth Vp Vs } & \text { Density }\end{array}$

$\begin{array}{cccc}0.00 & 2.50 & 1.10 & 2.10 \\ 0.50 & 4.00 & 2.10 & 2.40 \\ 3.00 & 6.20 & 3.60 & 2.80 \\ 18.00 & 6.60 & 3.70 & 2.90 \\ 32.00 & 7.30 & 4.00 & 3.10 \\ 41.00 & 8.20 & 4.63 & 3.40\end{array}$

Region 11 CRUST5.1 C4

$\begin{array}{llll}\text { Depth Vp } & \text { Vs } & \text { Density }\end{array}$

$\begin{array}{llll}0.00 & 1.50 & 0.00 & 1.02\end{array}$

$\begin{array}{llll}1.00 & 2.30 & 1.10 & 2.20\end{array}$

$\begin{array}{llll}3.00 & 3.20 & 1.60 & 2.30\end{array}$

$\begin{array}{llll}4.50 & 6.00 & 3.40 & 2.70\end{array}$

$\begin{array}{llll}14.00 & 6.60 & 3.70 & 2.90\end{array}$

$\begin{array}{llll}24.00 & 7.20 & 4.00 & 3.10\end{array}$

$\begin{array}{llll}32.00 & 8.20 & 4.63 & 3.40\end{array}$ 


\begin{tabular}{cccc} 
Region 12 & \multicolumn{3}{c}{ CRUST5.1 A0* } \\
Depth & Vp & Vs & Density \\
\hline & & & \\
0.00 & 1.50 & 0.00 & 1.02 \\
3.00 & 1.80 & 0.70 & 1.70 \\
3.15 & 5.00 & 2.50 & 2.60 \\
4.85 & 6.60 & 3.65 & 2.90 \\
7.15 & 7.10 & 3.90 & 3.05 \\
9.15 & 7.90 & 4.46 & 3.40
\end{tabular}




\section{Figure Captions}

Figure 1. Map of western Eurasia used to develop the conceptual WEA model. We show the topography and bathymetry that have been obtained from the ETOPO5 model. The epicentral location of earthquakes in this region with magnitudes greater than 4.0, obtained from the NEIC bulletin, are shown. The aseismic nature of most of WEA is apparent. The locations of permanent, three-component, broadband stations are also shown. The scale, in meters, indicates the topography and bathymetry.

Figure 2. Map of the conceptual WEA model. Individual regions are color coded and their boundaries have been noted.

Figure 3. Map showing the WEA regions on top of some of the Exxon maps (Kaplan et al. [1985]) of the region. The region boundaries have been adjusted to track some of the geologic features in the Exxon map. Also shown is the MENA1.1 model of Walter et al. [2000] to demonstrate that the boundaries match exactly between the models.

Figure 4. Map showing the geo-coded $1^{\circ} \times 1^{\circ}$ digitized computer model WEA. 


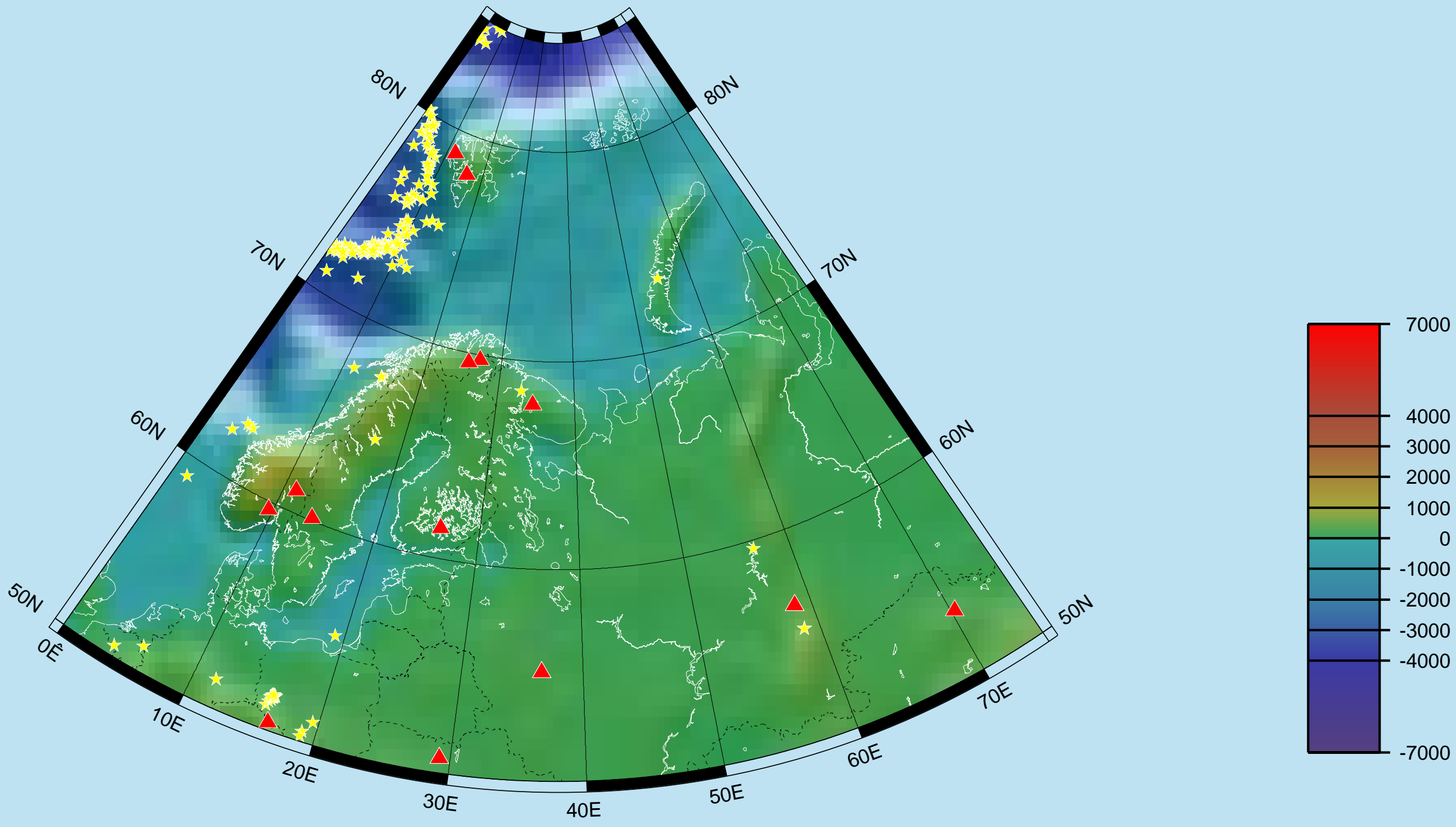

- Seismic Stations

Figure 1 Earthquakes $\left(m_{b}>4.0\right)$ 


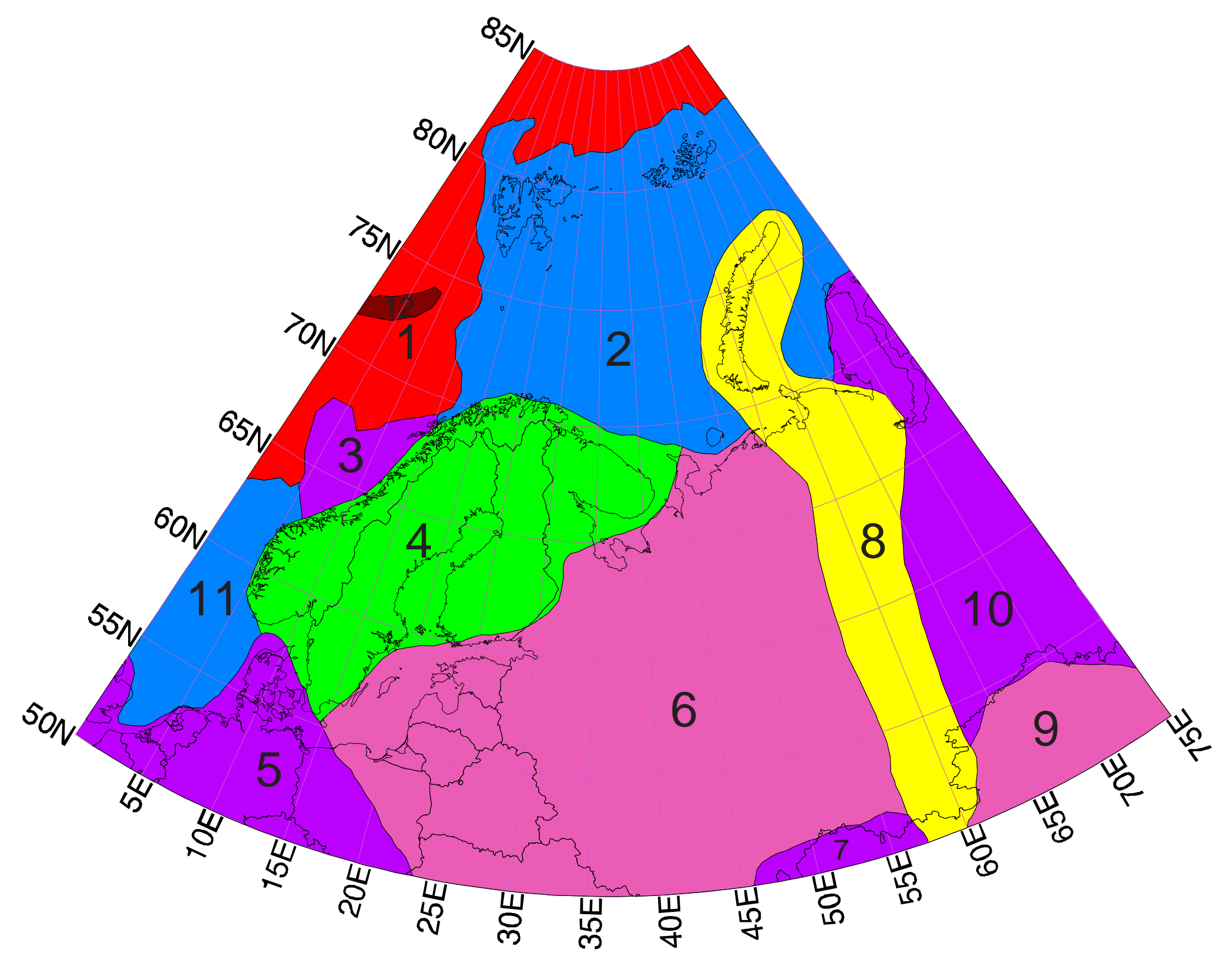

Figure 2 


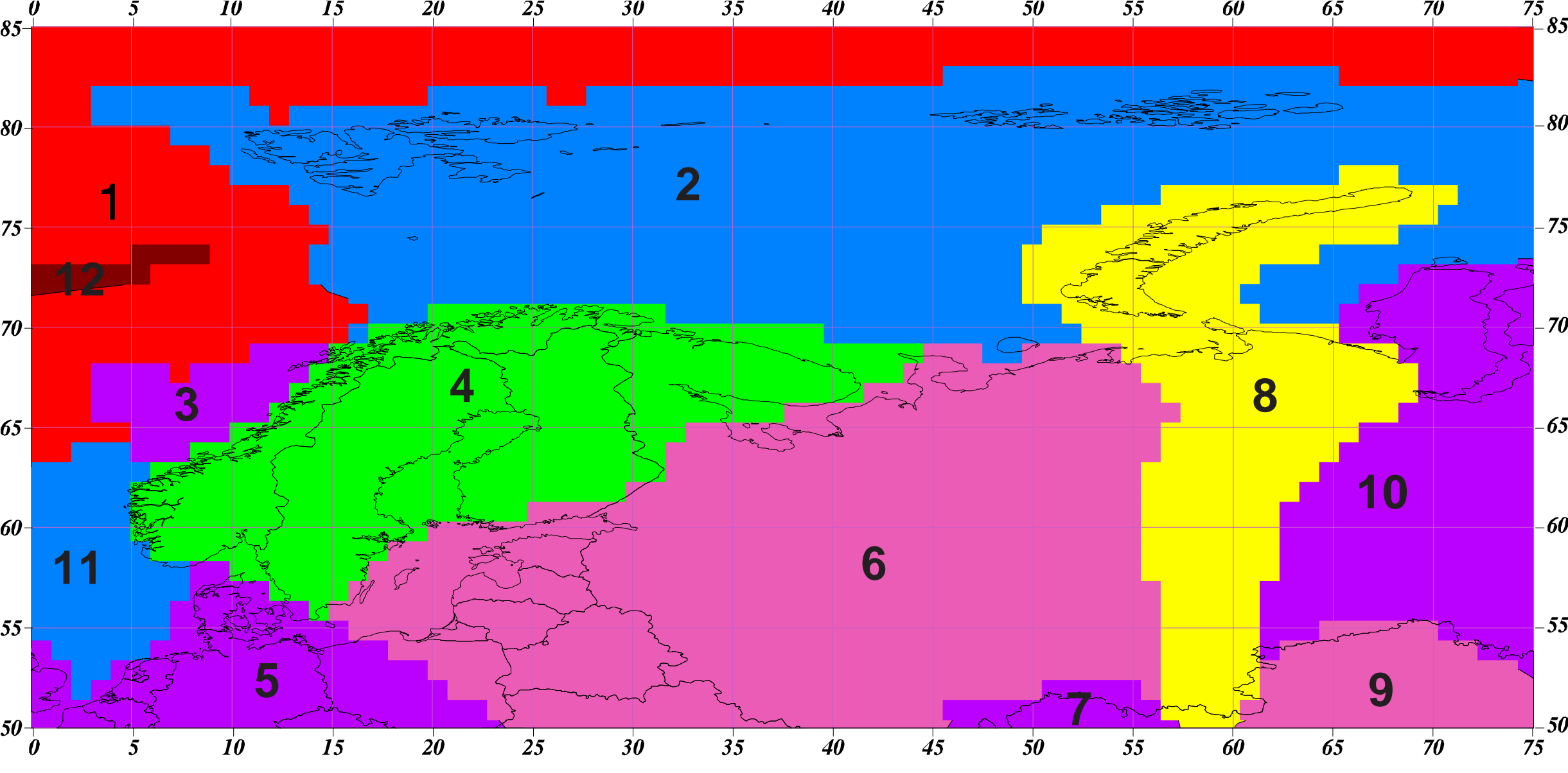

Figure 3 


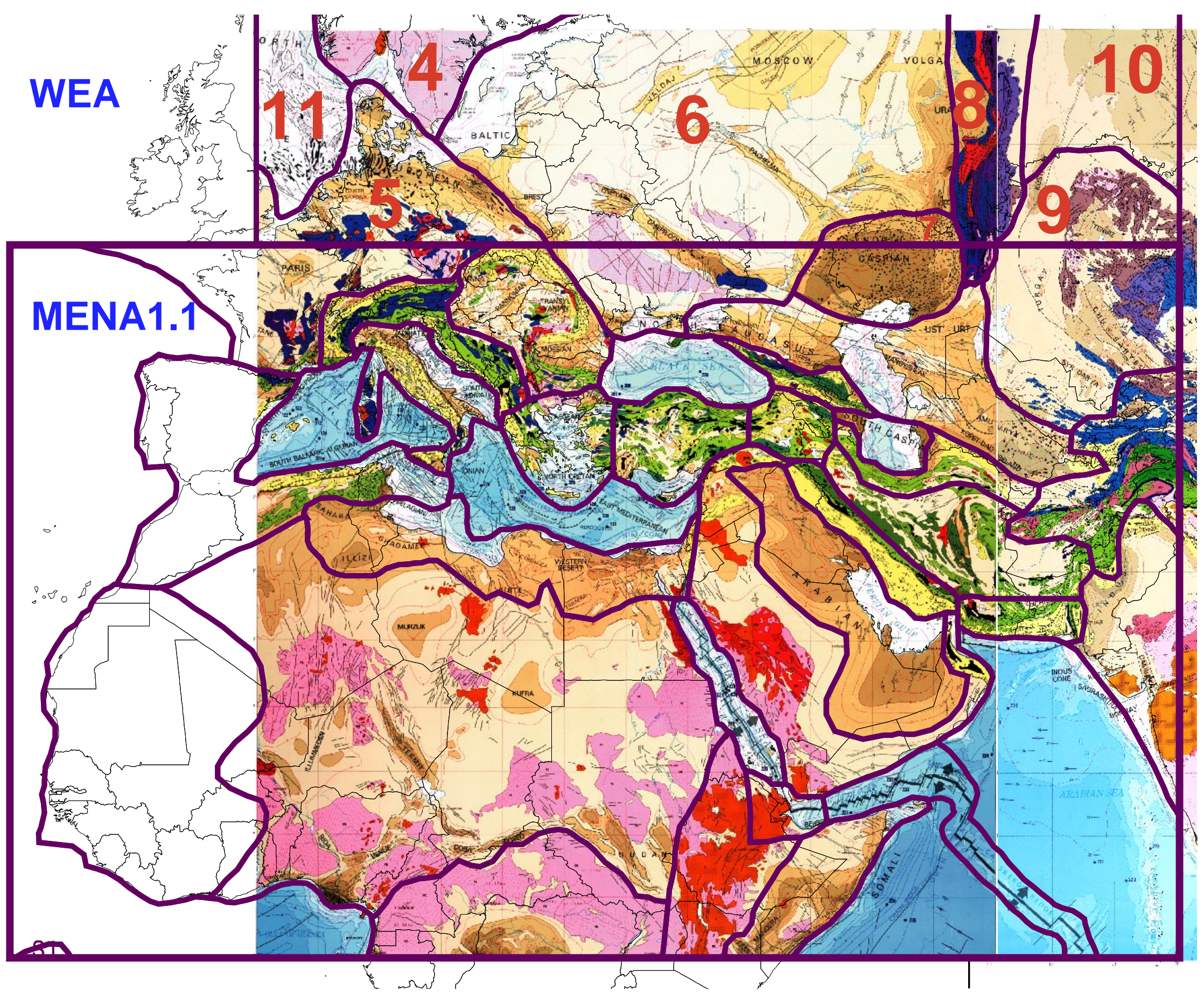

Figure 4 